\title{
Mexican tradition and continuity on Manuel Parra Mercado's (1911-1997) works: a statement for locality
}

During the decade of the 1920 Mexican Architecture abandoned the traditional home design scheme to embrace Functionalism. In the international scene, new technologies and materials were regarded as the solutions for society, and in the Mexican case, it was also a demonstration of progress. During the following decades functionalist governmentfunded architecture prevailed, but it lacked the elements to consider it as "Mexican". In spite of the official support to this architecture, other currents emerged, sparked by a rediscovered national identity. It was, as David Leatherbarrow (2002) describes, a conflict between place and production in modern architecture as a disruptive relationship of technology destroying topographical coherence and cultural continuity. This idea draws from the conception that technical objects are produced independent of territorial considerations, while buildings never are. It can also be understood as an issue between the globalities, represented by modern functionalist design (buildings conceived as technical objects), its construction materials and technologies; and localities, characterized by traditional hand crafted materials and techniques associated with the building site.

Due to the qualities of his built work and design, Manuel Parra did not address the issue by combining industrialized materials with traditional crafts, but rather by introducing an atypical use of traditional and recycled materials, colonial and archeological, and their techniques with the site's topology. The resulting compositions represent an alternative form of home building and interior design for modern living that retain cultural identity. design, interiors, identity, dwelling, site

\section{Introduction}

By the end of the nineteenth century, in his effort to modernize the country, Mexican dictator Porfirio Díaz adopted French positivism as a model of progress. This was a period of architectural eclecticism, mostly inspired by Beaux Art classicism. In this attempt of modernization many colonial and baroque buildings were tore down in downtown Mexico City. Nevertheless, those that survived preserved many qualities that defined them as "Mexican", referenced to the Spanish heritage. Soon, during the time of the Revolution, there were many neo-colonial buildings that were "accepted" by the new regime as a rejection of porfirian era French-influenced style.

After the Mexican Revolution and its following civil wars, the government of the 1920's required a physical platform to reconstruct the nation, with social needs as a priority: 
education, public health and affordable housing. At the same time, it was the moment to construct a new national representation of "Mexicaness". To that purpose, the Secretary of Education, José Vasconcelos, a staunch antipositivist, devised a program in which Mexico acknowledged its pre-Hispanic past, its native culture as well as the resulting popular arts and customs derived from the "mestizaje" process. He was convinced that arts had the potential for social transformation.

Vasconcelos' ideals had a great impact on the field of visual arts and soon other forms of expressing nationalism incorporated elements from pre-Hispanic cultures. In architecture, more specifically, perhaps the most well known example is the Mexican version of Art Déco, which in turn led to other short-lived alternatives, regarded as archaeological reconstructions such as "Indianism" and "Primitivism" (Fraser, 2001: 38). These literal imitations, far from experimental, became the first efforts to reconcile Mexico's exemplary past with the construction of a better present and future, but lacked the potential for renewal. It was, as Coleman (2005: 24) expressed, a yearning for the age of gold, or from a religious point of view, the search for paradise.

Gradually these forms of architecture and design were replaced by modern functionalism, which in turn suited the aims of México's Revolutionary government, for it sought simplicity and efficiency based on the model of technology and industrial development. Reinforcing this vision, academics and professionals were deeply influenced by Le Corbusier's seminal book Vers une architecture (1923), in which a house was understood as a machine for living, in itself the most well known utopia in 2oth century architecture. Based on modern construction techniques, architecture was conceived from the perspective of efficiency and comfort, but lacked the symbolic meaning for dwelling from the perspective of Mexican culture.

In spite of the official support to functionalist modernism, other forms of architecture, industrial and interior design proved to be quite popular. From the 1920's onward, middle and upper classes developed in large cities and as a consequence, urban lifestyles evolved, shifting tastes towards "modern" housing, but not necessarily in opposition to "tradition" (Winfield-Reyes, 2010: 10). As Fraser points out, there was no rupture; it was an "evolutionary rather than a revolutionary change" (Fraser, 2001: 28). It was on its own right the process of cultural continuity following the construction of the national identity that had been promoted decades earlier. In this architectural and ideological background Parra started his professional career.

\section{Manuel Parra's backgrounds}

Manuel Parra (1911-1997) enrolled in 1930 as an architecture student at Academia de San Carlos, Mexico's most prestigious Fine Arts school, where he exhibited his remarkable talent for drawing and painting. While he continued his professional studies, he also worked as a freelance draughtsman and illustrator for architect Santiago Greenham. During this period, the architecture program at the Academia de San Carlos underwent some profound directional changes, most of them promoted by José Villagrán, an active practitioner and advocate of functionalist architecture. As the head of the Architecture Department at Academia de San Carlos in the 1920's, José Villagrán introduced the functionalist vision of architecture to tackle social problems from a modern theoretical, technical and practical perspective, which in turn aligned to the government's objectives, becoming itself an ideological posture. Although Parra was reluctant to this new form of architecture theory and design practice, Villagrán had many followers, among them Juan 
O'Gorman one of Parra's friends and most successful architects-to-be in the near future.

In 1936, Parra presented his thesis project stating "there is no doubt that the problem of housing is and will always be of paramount importance for architecture" which became his personal statement for the rest of his life. In the context of modernization, Parra rejected the mechanistic vision of architecture and sought after a different perspective, modern yet meaningful for dwelling.

In several occasions he travelled to Europe, Spain in particular, where he studied the original sources of Hispanic heritage: formal and vernacular construction techniques, hand crafted furniture, pottery and ceramics that had become part of the Mexican identity. He not only found the original models, but also understood the variations that spanned from Southern Spain up to the Pyrenees. With this growing knowledge of inherited construction and hand craft techniques, his interest on pre-Hispanic and popular arts, his understanding of the topographical conditions of the buildings' sites, Parra developed a form of architecture and design that stood out of the mainstream trends and in clear opposition to them.

His architecture and design can be described in Nathaniel Coleman's (2005) terms, in which architecture's utopian character is determined by its exemplarity, achieved by a "negation of the conditioning perspectives of the present, which is characterized by abstractness, ironic distance, commodification and the isolation of spectacle". In this sense, Coleman's insights can be applied as well to interiors, furniture design and crafts.

\section{Shaping sites for human dwelling, 1936-1997}

Parra's work spanned from 1930 through the 1990 designing many remarkable residences around suburban towns in southern sections of Mexico City like Coyoacán and San Ángel as well as other states, mainly Guanajuato and Veracruz. Although his constructions featured decorative elements from pre-Hispanic or colonial eras, the overall compositions did not fit in the nationalist category. His goal was not to make contributions to a national identity but rather to provide meaningful dwelling places for his clients. Although modern, his houses did not fit in functionalism either.

His architecture and interiors were conceived to fulfill the resident's desires, needs and realities. In some regards, many of his houses also portray his sense of humor. His friends nicknamed him "El Caco" ("The thief") because he would often "steal" rubble from demolished colonial buildings and playfully use it for his own architectural work.

From the 1940 s to the 1950s, Parra had brief involvement as a set designer for cinema productions directed by his friend Emilio "El Indio" Fernández, whose films reflected the ideals of the Mexican Revolution, and represented the conflicts of rural México and the contrasting urban social inequalities. In these films Parra designed hacienda and some cabaret interiors. Later, the filmmaker commissioned Parra to design and build his house in Coyoacán, a house that was used as a residence and as a location for shooting films. It is believed that it took 25 years to finish this house.

From the 1950 s onward, the modern Mexican house incorporated new conveniences such as refrigerators, washing machines and cars, which added a new set of specific spaces to be considered for these new modern life items. Parra found all these technological products distasteful and continually designed concealing cabinets for them. 


\section{The reconciliation with the past: rediscovering locality}

Unlike Art Déco and other "indianisms" Parra achieved the reconciliation with the past by inventing an architecture that does not replicate historical forms but rather incorporates references of Mexico's cultural heritage -both pre-Hispanic and colonial- in the present. He distanced from the neo-colonial, "primitivist" and functionalist schemes and developed an architecture that is better understood from the standpoint of experience. This way he established a counterpoint to the prevailing modes of production, particularly against early functionalist architecture, where industrial mass-produced construction materials, globalities, led to a reductionist vision of inhabitance. As Van Eyck stated, modern architecture expressed its "severest limitation byway of its adherence to physical functionalism" (Coleman, 2005: 227). It should be noted that as upper classes started accepting the aesthetic discourse of functionalism, which in turn abandoned the social agenda from its formative origins, it became known as the International Style.

In turn, Parra used several strategies to design and build his clients' homes. First, he deliberately integrated the buildings to the landscape, adapting them to its features, fending off the free plane orthogonal formula from the functionalists. He studied the lighting conditions and the site's topology to understand its effects on the home structure and its dwellers. As a result, these homes are a multileveled sequence of both, exterior and interior interconnected spaces.

Then he constructed them using materials that were provided by the local surroundings. The basic structures were built with volcanic rock, an abundant asset in central México, as well as fired bricks, Talavera ceramic tiles and timber, instead of concrete and steel beams. From the beginning, these traits enhanced the emotional connections to the house and its location. Additionally, these materials provided a palette of warm and neutral colors, in contrast with the colorless scheme of modern international styles.

He then laid out a floor plan that broke away from the straightforward approach of the functionalists but also from the neocolonial and neopre-Hispanic schemes. He avoided the austere transparency and open flowing interiors that characterized "International Styled" houses, which echoed the growing industrial era. By doing so, his works counterpoint the paradigms of the International Style: transparency vs. enclosure, open and flexible vs. closed and defined, free façade vs. main façade, void vs. solid. In brief, he established the dialectics of locality vs. globality. These homes do not rationalize human patterns, they were meant to enhance human interactions and experience.

Markers are another distinctive aspect of Parra's work, a feature purposely ignored by functionalist architecture. To this respect, Manuel Martín [2003] established differences between classical dwelling and modern dwelling, stressing the importance of markers on the former, and on how modern architecture and interiors had on purpose omitted its place in the modern house. Martín criticizes the latter for restraining the inhabitant to leave his own array of traces and markers; modern interiors became the scenography for the "yearning of a harmonious inhabitancy, where the civilized man, metropolitan and free, lacked his own origins and culture". However, in today's globalized context it should be pointed out that there has been a transition in the field of interior design in which contemporary designers have now become aware that "ethnicity is a quality to be respected" (Gibbs, 2005: 34).

Parra defined the physical limits of public zones and private interiors within the house 
and heightened its character, using permanent and movable markers. Permanent markers such as combined flooring materials accentuated by split-level elevations, emphasizing the area, define transitions. He then complicated the composition using asymmetrical spaces, delimited by brick columns and stone arches, wood beams, curving stone stairs and hallways. Consequently, decontextualized building materials became permanent markers throughout the home.

For movable markers, such as furniture and accessories, (elements that most studies have not examined) Parra applied the same criteria he used to build his homes: use materials provided by the local surroundings, develop a playful and unexpected assembly of parts and employ a naïve worker's hand. His furniture mostly made of burnished wood, combines irregular and symmetrical shapes, giving interiors their distinctive character. Reusing wood that formerly was used for doors and windows in particular, Parra made table counters and indoor benches for his clients. As for the legs for these structures, his repertoire would include Y-shaped branches, wooden sculptures and engraved colonial corbels. For other furniture pieces such as cabinets and alike, he would employ the juxtaposition of different wood types in order to create patterns and motifs, referencing the Spanish-Arabic roots of Mexican culture. In most of his furniture work, Parra expresses mass rather than volume.

All of these markers are used in a similar manner as romans from the Late Empire used spolia, under Alchermes' premises (Alchermes, 1994: 168). In his study on "Roman cities from the Late Empire", he explains that Roman rulers and residents had already used this term as an architectural reuse. While modern scholarly works depict spolia as "unprincipled architectural scavengers preying on the ruins" of destroyed buildings, he argues that this practice had the purpose of preserving the monuments and the civic spirit that had created them. Likewise, influenced by Vasconcelos' ideas, Parra's use of demolition parts and their materials, honors the memory of Mexican heritage, both, Spanish and pre-Hispanic as well as Mexican popular arts.

\section{Conclusion}

Parra's design statement can be considered as an example of cultural continuity in a context of global modernity. Every element, newly handcrafted and archeological, contributes a part of its history, carefully selected and rearranged in the new environment, fulfilling the reconciliation with the past, and therefore preserving the spirit that produced each one of them. Parra's contribution to interior design is not just an aesthetic signifier of Mexican identity; his homes pay tribute to craft and vernacular tradition, a hint of México's exemplary past but at the same time enhances modern living. Consequently Parra achieved addressing the respect for locality in a global context.

\section{References}

ALCHERMES, Joseph, "Spolia in Roman cities of the late empire: Legislative rationales and architectural reuse", Dumbarton Oaks Papers, 48, pp. 167-178, 1994.

COLEMAN, Nathaniel, Architecture and utopias, Oxon, Routlegde, 2005, 353 p.

FRASER, Valerie, Building the new world: studies in modern architecture of Latin America 1930-1960, Verso, London, 2001.

GIBBS, Jenny, Interior design, London, Laurence King Publishing, 2005, 224 p.

LEATHERBARROW, David, Uncommon ground: Architecture, Technology and Topography, MIT Press, Boston, 2002, ISBN: o 262621614. 
theme 3

identity strand 2

localities / globalities

PARRA, Manuel, Tesis profesional de Manuel Parra Mercado, 1936, UNAM archive. MARTÍN, Manuel, "La pregunta por el habitar moderno", in Solá-Morales, et al. (2003). Teorías de la arquitectura. Barcelona: Ediciones UPC VALDÉS, Adriana, Manuel Parra y San Ángel, Metodología Arquitectónica, México, Tampico, Tamaulipas: Instituto Politécnico Nacional, 1998 WINFILED-REYES, Fernando N., On the diffusion of modernist urban models: An overview of Mexico City's planning and urban design projects (1921-1952), Planum, 2010, pp.2-23 